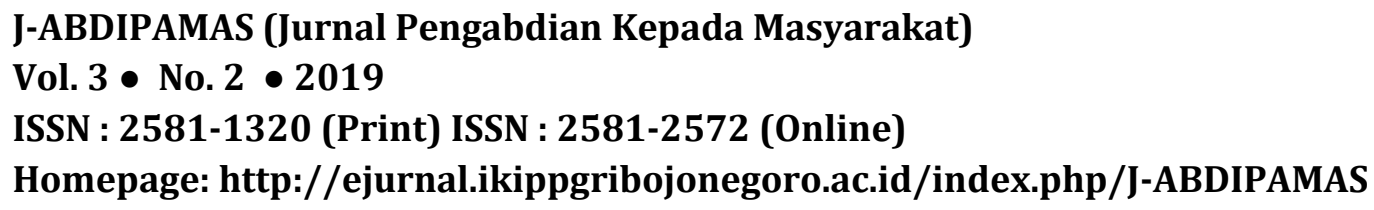

\title{
PENGGUNAAN ALAT PERAGA TIMBANGAN PADA MATERI BILANGAN ASLI DAN KESETIMBANGAN
}

\author{
Tika Karlina Rachmawati ${ }^{1}$, Ehda Farlina ${ }^{2}$, Winda Setya ${ }^{3}$,T. Tutut Widiastuti. A $^{4}$ \\ ${ }^{1}$ UIN Sunan Gunung Djati Bandung. Email: tikakarlinarachmawati@uinsgd.ac.id \\ 2UIN Sunan Gunung Djati Bandung. Email: ehda.farlina@uinsgd.ac.id \\ 3UIN Sunan Gunung Djati Bandung. Email: windasetya@uinsgd.ac.id \\ ${ }^{4}$ UIN Sunan Gunung Djati Bandung. Email: widiastuti@uinsgd.ac.id
}

\begin{abstract}
Natural Numbers is one of many Mathematics subjects given in elementary school. One of material that is learned in Natural Numbers is the Numerical Count Operations, Lack of use of teaching aid by the teacher to explain the material Operations to Calculate Natural Numbers makes students not really get what is taught. Therefore, one of the solutions is to conduct training on teaching aidsequilibrium. The purpose of this training is to introduce the concept of equilibrium uses the teaching aid of the scales in the operation of calculating natural numbers in mathematics as it ison equilibrium material in science lessons. This Community service activity use straining methods. It is a training using the teaching aid. This community service that is based on training aimed to grade IIIA and IIB students at MI At Taqwa Rancaekek, Bandung Regency. This activity was done July 31, 2019. On this activity most students already understood the operation of natural numbers is addition, subtraction, multiplication, and equilibrium by using scales. While mistakes that many students did was when students tried the teaching aid, they hung on the beam's position wrong either the right arm or the left arm
\end{abstract}

Keywords: teaching aid, scales, natural numbers, equilibrium

\begin{abstract}
ABSTRAK
Bilangan Asli merupakan salah satu materi mata pelajaran Matematika yang diberikan di SD. Salah satu yang dipelajari pada Bilangan Asli adalah Operasi Hitung Bilangan Asli. Kurangnya penggunaan alat peraga untuk menjelaskan materi Operasi Hitung Bilangan Asli membuat siswa mengalami kebingungan. Oleh karena itu, salah satu solusinya adalah mengadakan pelatihan tentang alat peraga timbangan. Tujuan diadakannya pelatihan ini adalah mengenalkan konsep kesetimbangan dengan menggunakan alat peraga timbangan pada operasi hitung bilangan asli di pelajaran matematika sekaligus pada materi kesetimbangan di pelajaran IPA. Kegiatan pengabdian kepada masyarakat ini menggunakan metode pelatihan. Pelatihan yang dimaksud adalah pelatihan dengan menggunakan alat peraga timbangan. Pengabdian kepada masyarakat berbasis pelatihan ini ditujukan kepada siswa kelas IIIA dan IIIB MI At Taqwa Rancaekek, Kabupaten Bandung. Kegiatan ini dilaksanakan pada tanggal 31 Juli 2019. Pada kegiatan ini, sebagian besar siswa sudah memahami operasi bilangan asli yaitu penjumlahan, pengurangan, perkalian, dan kesetimbangan dengan menggunakan alat peraga timbangan. Sedangkan kesalahan atau kekeliruan yang banyak dilakukan siswa adalah pada saat siswa mencoba alat peraga timbangan yaitu kesalahan siswa dalam menggantungkan posisi balok baik di lengan kanan atau lengan kiri.
\end{abstract}

Kata Kunci: alat peraga, timbangan, bilangan asli, kesetimbangan 


\section{PENDAHULUAN}

Mata pelajaran Matematika merupakan salah satu mata pelajaran yang diberikan di SD, SMP, maupun SMA. Matematika berhubungan erat dengan kehidupan sehari-hari, seperti pada jual beli. Matematika diberikan dari siswa SD bertujuan untuk membekali siswa agar dapat berpikir secara sistematis dan logis. Dengan diajarkannya berpikir secara sistematis dan logis sejak dini, diharapkan dapat membekali siswa dalam berpikir memecahkan suatu permasalahan.

Materi Bilangan Asli merupakan salah satu materi yang diberikan di SD. Materi ini diberikan sejak kelas satu di SD. Bilangan Asli membahas tentang pengertian Bilangan Asli dan Operasi Hitung pada Bilangan Asli. Operasi hitung Bilangan Asli meliputi operasi penjumlahan, pengurangan, perkalian dan pembagian. Dalam karya ilmiahnya, (Sedyoningrum \& Supeni, 2017) menyatakan bahwa metode guru dalam mengajar masih kurang bervariasi dan guru kurang menyertakan alat peraga yang tepat, sehingga siswa merasa bosan dan kurang memperhatikan pada saat guru mengajar. Sedangkan (Sari, 2013) menemukan permasalahan di SLB Wacana Asih Padang yaitu satu dari 5 anak yang tunagrahita ringan di kelas II belum dapat mengerjakan penjumlahan sampai 10, dan hanya dapat mengerjakan penjumlahan sampai dengan 5. Dimana setelah diidentifikasi, 4 orang anak yang lainnya mampu menyelesaikan penjumlahan bilangan sampai sepuluh. Sedangkan kurikulum menuntut agar anak mampu mengerjakan penjumlahan sampai dengan 10. Menurut (Rachmawati, Suhendar, \& Akbar, 2018) menjelaskan bahwa pembelajaran pada bilangan bulat di SD dengan menggunakan metode ceramah dan menjelaskan operasi hitung bilangan bulat tanpa menggunakan alat peraga sehingga membuat proses pembelajaran menjadi kurang efektif karena siswa menjadi pasif.

Penulis tertarik untuk mengadakan pelatihan tentang alat peraga yang berhubungan dengan operasi hitung pada bilangan asli. Salah satu alat peraga yang digunakan untuk menjelaskan dan memberikan pemahaman tentang operasi hitung pada bilangan asli adalah alat peraga "Timbangan". Alat peraga ini juga dapat menjelaskan tentang materi keseimbangan pada mata pelajaran IPA. Hasil penelitian (Sedyoningrum \& Supeni, 2017) menyatakan bahwa dengan menggunakan alat peraga timbangan dapat meningkatkan hasil belajar matematika pada materi pembagian kelas III SD Negeri 03 Kaliwuluh, Kebakkramat, Karanganyar. Sedangkan penelitian (Sari R. N., 2018) menyatakan bahwa hasil belajar yang menggunakan alat timbangan numerik lebih baik dibandingkan dengan pembelajaran tanpa menggunakan alat peraga (jarimatika) pada konsep perkalian siswa kelas II SDI Al Azhar 15 Pamulang.

Dari identifikasi permasalahan tersebut, penulis tertarik untuk mengadakan pengabdian kepada masyarakat dengan mengadakan pelatihan menggunakan alat peraga timbangan kepada siswa kelas III SD/MI. Tujuan diadakannya pelatihan ini adalah mengenalkan konsep kesetimbangan dengan menggunakan alat peraga timbangan pada operasi hitung bilangan asli di pelajaran matematika sekaligus pada materi kesetimbangan di pelajaran IPA. Pengabdian kepada masyarakat berbasis pelatihan ini ditujukan kepada siswa kelas IIIA dan IIIB MI At Taqwa Rancaekek, Kabupaten Bandung. Setelah diadakannya pelatihan, diharapkan siswa kelas III MI At Taqwa dapat memahami 
konsep operasi hitung bilangan asli dan kesetimbangan dengan menggunakan alat peraga timbangan.

\section{METODE PELAKSANAAN}

Kegiatan pengabdian kepada masyarakat ini menggunakan metode pelatihan. Pelatihan yang dimaksud adalah pelatihan dengan menggunakan alat peraga timbangan. Angket dan dokumentasi merupakan data yang dikumpulkan oleh pengabdi. Siswa kelas III MI At Taqwa mengisi angket yang telah diberikan setelah diadakannya pelatihan alat peraga timbangan. Angket yang digunakan merupakan angket tertutup sebanyak 10 pernyataan dengan menjawab "Ya" atau "Tidak". Pada angket terdapat 7 pernyataan positif dan 3 pernyataan negatif. Data yang telah diperoleh kemudian dianalisis dengan menggunakan metode deskriptif.

Ada tiga tahapan dalam pelaksanaan pengabdian kepada masyarakat yaitu persiapan, observasi dan pelaksanaan pengabdian kepada masyarakat. Tahap persiapan yaitu menyiapkan alat peraga timbangan serta membuat angket yang akan disebarkan. Dalam tahap ini, tim pengabdi membuat alat peraga timbangan dari kayu dan menyiapkan mistar dari besi sebagai lengan dari timbangan. Angka dari mistar ini hanya dibatasi sampai dengan 10 yaitu 10 ke kanan dan 10 kekiri. Alat peraga timbangan yang dimaksud dapat dilihat pada Gambar 1 berikut.

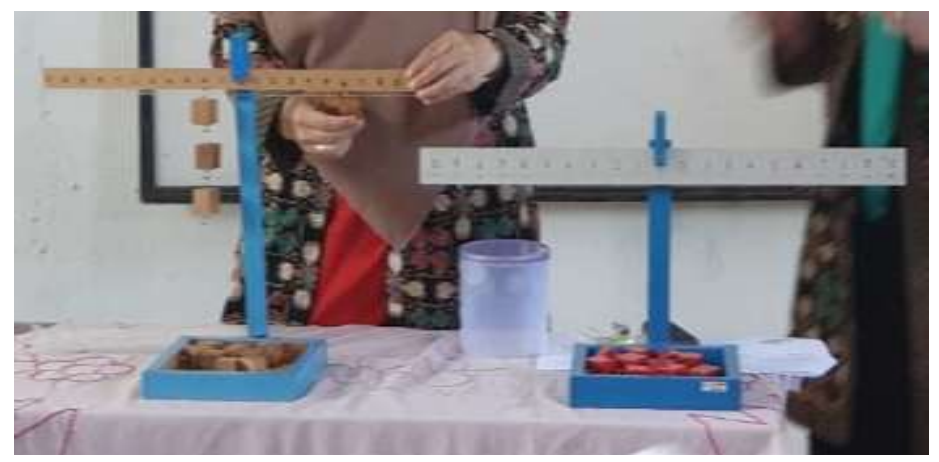

Gambar 1. Alat Peraga "Timbangan"

Tahapan yang kedua adalah observasi. Observasi dilakukan pada Senin, 29 Juli 2019. Kegiatan observasi ini dilakukan untuk meminta ijin mengadakan kegiatan pengabdian kepada masyarakat. Pengabdi menemui kepala MI At Taqwa, wali kelas IIIA dan IIIB untuk meminta ijin mengadakan pengabdian kepada masyarakat. Pada observasi ini, pengabdi juga mengumpulkan data seperti jumlah siswa kelas IIIA dan IIIB, kesepakatan hari dan waktu diadakannya pengabdian. Dari kesepakatan antara pengabdi dengan wali kelas III MI at Taqwa, maka diperoleh kesepakatan bahwa hari Rabu, 31 Juli 2019 pukul 08.00 diadakannya kegiatan pengabdian.

Tahapan setelah observasi yaitu pelaksanaan kegiatan pengabdian kepada masyarakat. Kegiatan ini dilakukan pada hari Rabu, 31 Juli 2019 di MI At Taqwa Rancaekek. Kelas yang pengabdi gunakan untuk diadakan pelatihan adalah kelas IIIA dan IIIB. Pada pukul 08.00 WIB sampai dengan 09.00 WIB diadakan pelatihan di kelas IIIB sejumlah 20 siswa. Berikut foto pelaksanaan pelatihan alat peraga timbangan di kelas IIIB dapat dilihat pada Gambar 2. 


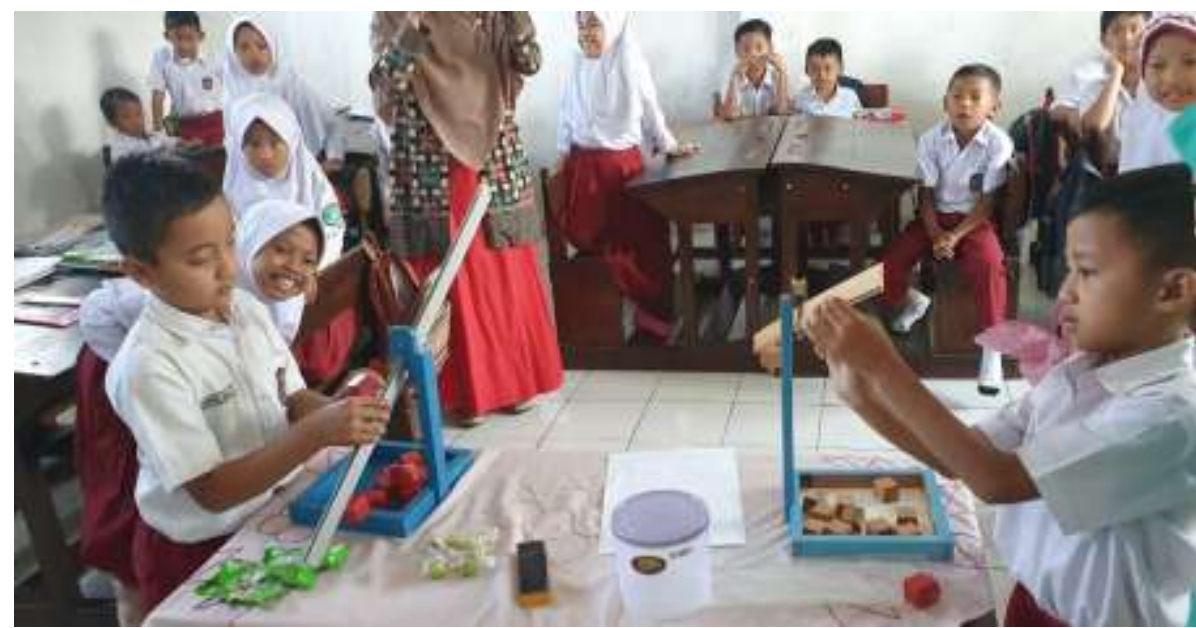

Gambar 2. Pelaksanaan Kegiatan di kelas IIIB

Sedangkan untuk kelas IIIA pada pukul 09.00 WIB sampai dengan 10.00 WIB sejumlah 23 siswa. Kegiatan pelatihan untuk kelas IIIA dapat dilihat pada Gambar 3 berikut ini.

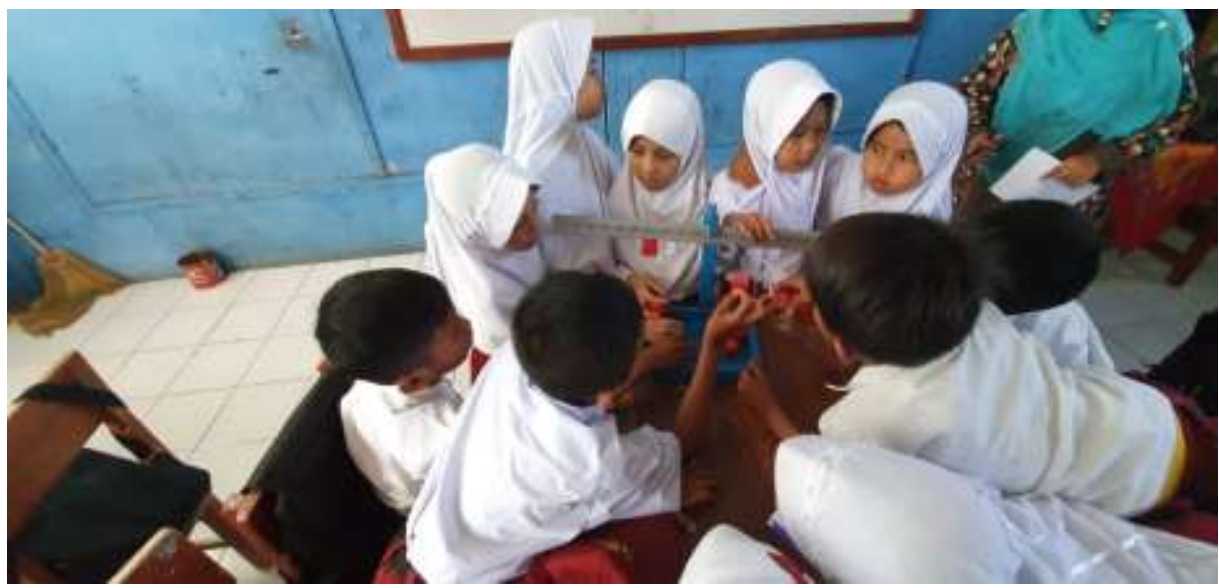

Gambar 3. Pelaksanaan Kegiatan di Kelas IIIA

Pada kegiatan pelatihan alat peraga timbangan, tim pengabdi mengajarkan kepada siswa operasi hitung penjumlahan, pengurangan, perkalian, pembagian bilangan asli beserta materi kesetimbangan untuk pelajaran IPA. Karena keterbatasan alat, maka operasi hitung bilangan asli hanya dibatasi sampai dengan 10. Setelah diadakannya pelatihan dengan menggunakan alat peraga timbangan, tim pengabdi membagikan angket yang berisi 10 pernyataan kepada siswa. Siswa hanya mengisi angket dengan jawaban "Ya" atau Tidak".

\section{HASIL DAN PEMBAHASAN}

Hasil dari kegiatan pengabdian kepada masyarakat yang dilaksanakan di MI At Taqwa Rancaekek ini meliputi hasil pelaksanaan dikelas pada saat pelatihan dan hasil angket sesudah diadakan pelatihan.

\section{Hasil Pelaksanaan Pelatihan}

Kegiatan pengabdian kepada masyarakat ini dalam bentuk pelatihan alat peraga timbangan. Pelatihan ini ditujukan kepada siswa kelas III MI At Taqwa Rancaekek sejumlah 43 siswa yang terdiri dari 23 siswa kelas IIIA dan 20 siswa kelas IIIB. Alat peraga timbangan menjelaskan konsep tentang operasi hitung bilangan asli dan kesetimbangan. 
Dalam hal ini, operasi hitung yang pengabdi ajarkan adalah penjumlahan, pengurangan, perkalian dan kesetimbangan. Ada beberapa kesulitan atau kesalahan siswa dalam mengoperasikan bilangan

Pada operasi hitung penjumlahan bilangan asli, ada beberapa siswa yang masih kebingungan meletakkan balok yang akan digantungkan. Siswa kebingungan meletakkan posisi balok untuk soal dan posisi balok untuk jawaban sehingga ada beberapa siswa yang tertukar letaknya seperti pada Gambar 4 berikut ini.

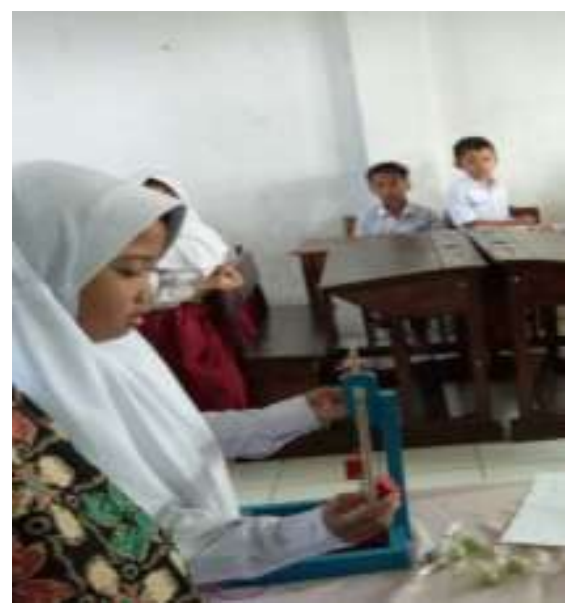

Gambar 4. Siswa yang Keliru Menempatkan Posisi Balok

Pada Gambar 4 menunjukkan siswa masih keliru menempatkan posisi balok soal. Misal siswa disuruh menghitung $4+5$ dengan menggunakan alat peraga timbangan. Pada Gambar 4, siswa meletakkan posisi balok di angka 4 sebelah kiri dan posisi balok di angka 5 di sebelah kanan, sehingga siswa kebingungan dalam menempatkan posisi balok jawaban agar mencapai keseimbangan antara lengan kiri dan kanan. Seharusnya posisi kedua balok di lengan kiri yaitu di angka 4 dan angka 5. Sedangkan posisi balok jawaban ada di lengan kanan. Ada juga siswa yang berani tampil ke depan untuk mencoba mengerjakan soal penjumlahan dengan menggunakan alat peraga timbangan tetapi kesalahan siswa tersebut adalah mengerjakan tidak sesuai dengan soal yang diberikan. Contohnya, tim pengabdi memberikan soal $6+2$ tetapi siswa tersebut mengerjakannya 5 +3 .

Kesalahan siswa mengerjakan operasi pengurangan dengan menggunakan alat peraga timbangan adalah masih kebingungan dalam hal posisi balok. Misalkan ada soal 7 - 2 maka beberapa siswa masih kebingungan dalam meletakkan posisi balok untuk angka 7 dan posisi balok untuk angka 2. Siswa meletakkan balok di angka 7 lengan kiri dan posisi balok di angka 2 lengan kiri. Posisi balok untuk yang benar adalah menggantungkan balok di angka 7 pada lengan sebelah kanan dan menggantungkan balok di angka 2 pada lengan sebelah kiri. Selanjutnya gantungkan balok jawaban di angka berapa pada lengan kiri agar timbangan tersebut seimbang. Pada pengurangan ini, siswa juga menyelesaikan soal dengan cara mencoba - coba agar timbangan tersebut menjadi seimbang seperti yang terlihat pada Gambar 5. 


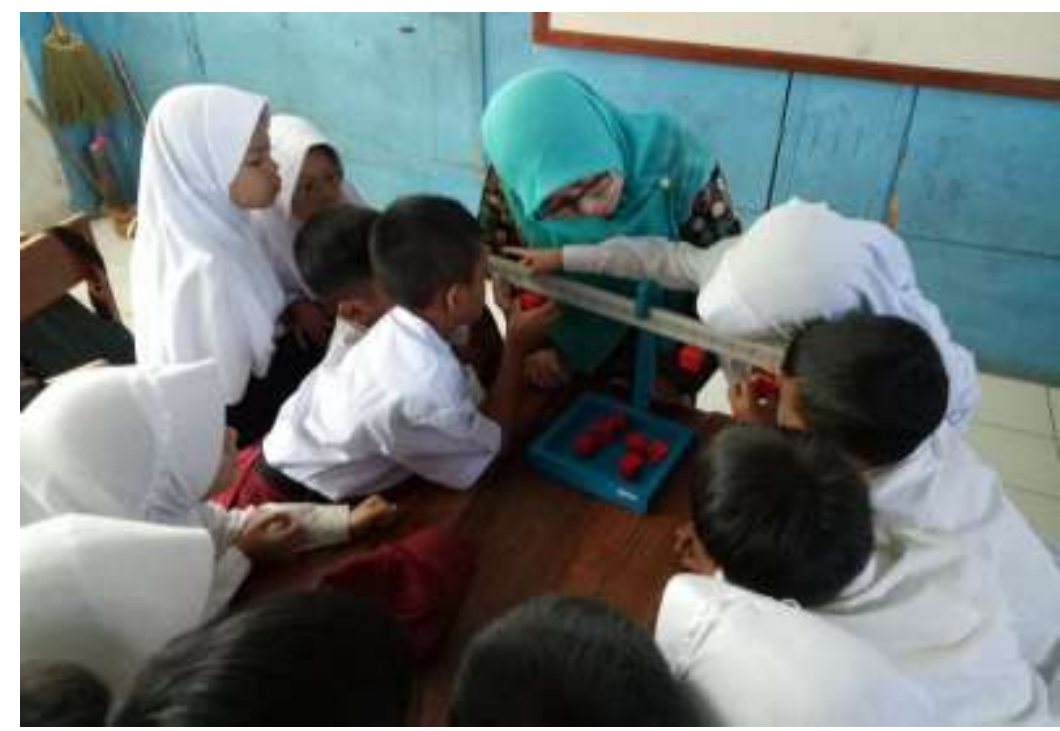

Gambar 5. Siswa Menyelsaikan Soal dengan Cara Mencoba-coba

Kesalahan siswa dalam mengoperasikan perkalian dengan menggunakan alat peraga timbangan adalah menggantungkan posisi balok jawaban dan kesalahan konsep perkalian seperti yang ditunjukkan pada Gambar 6 berikut ini.

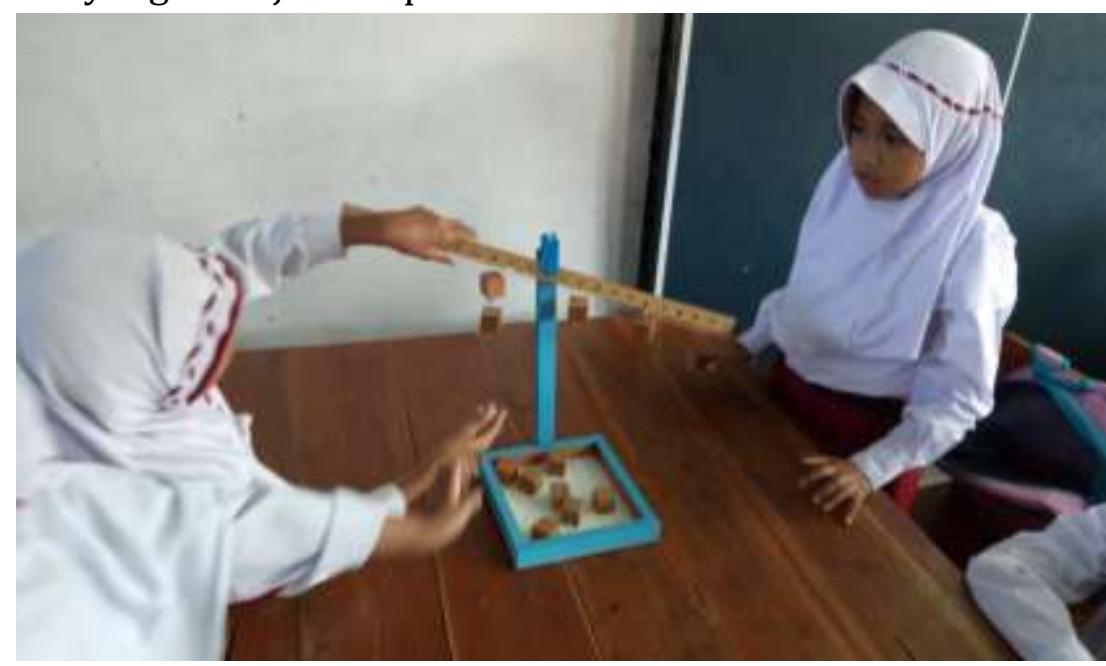

Gambar 6. Kesalahan Siswa dalam Mengoperasikan Perkalian

Pada Gambar 6 terlihat bahwa siswa masih keliru dalam menggantungkan balok untuk jawaban dari perkalian $3 \times 2$ yang diletakkan pada lengan kanan, sehingga terlihat tidak seimbang pada alat peraga timbangan tersebut. Kesalahan yang kedua adalah mengenai konsep perkalian. Sebagai contoh perkalian $3 \times 2$ dengan pekerjaan siswa adalah $3+3$ pada Gambar 6 . Konsep perkalian $3 \times 2$ adalah $2+2+2$ bukan $3+3$ walaupun sebenarnya jawaban sama.

\section{Hasil Angket}

Angket diberikan kepada siswa kelas III MI At Taqwa Rancaekek setelah siswa diberikan pelatihan alat peraga timbangan tentang operasi penjumlahan, pengurangan, perkalian bilangan asli dan kesetimbangan untuk pelajaran IPA. Angket tersebut diberikan kepada siswa untuk diisi dengan tujuan untuk mengetahui sejauhmana pemahaman siswa tentang penggunaan alat peraga timbangan. Hasil angket pada kelas IIIA sejumlah 23 siswa sebagaimana pada Tabel 1. 
Tabel 1. Hasil Angket Kelas IIIA

\begin{tabular}{clc}
\hline No & \multicolumn{1}{c}{ Aspek } & $\%$ \\
\hline 1 & Menyukai pelajaran matematika & $87 \%$ \\
\hline 2 & Menyukai pelajaran IPA & $87 \%$ \\
\hline 3 & Paham penjumlahan dengan alat timbangan & $87 \%$ \\
\hline 4 & Paham pengurangan dengan alat timbangan & $78,3 \%$ \\
\hline 5 & Paham perkalian dengan alat timbangan & $91,3 \%$ \\
\hline 6 & Paham kesetimbangan dengan alat timbangan & $74 \%$ \\
\hline 7 & $\begin{array}{l}\text { Semangat dalam pembelajaran jika menggunakan alat } \\
\text { timbangan }\end{array}$ & $91,3 \%$ \\
\hline 8 & Kebingungan dalam penggunaan alat timbangan & $0,1 \%$ \\
\hline 9 & Penjelasan alat timbangan kurang jelas & $0,1 \%$ \\
\hline 10 & Lebih paham menghitung biasa daripada dengan alat timbangan & $69,6 \%$ \\
\hline
\end{tabular}

Berdasarkan Tabel 1 diatas, siswa kelas IIIA sesudah mengikuti pelatihan tentang alat peraga timbangan bahwa siswa kelas IIIA sudah banyak yang paham tentang operasi penjumlahan, pengurangan, dan perkalian pada operasi bilangan asli. Siswa kelas IIIA juga sudah banyak yang paham tentang materi kesetimbangan di pelajaran IPA jika menggunakan alat peraga timbangan. Dari hasil sesudah diadakannya pelatihan, masih ada 0,1 \% siswa kelas IIIA yang masih kebingungan dalam menggunakan alat peraga timbangan. Sedangkan hasil angket pada kelas IIIB sejumlah 20 siswa ditunjukkan pada Tabel 2.

Tabel 2. Hasil Angket Kelas IIIB

\begin{tabular}{clc}
\hline No & \multicolumn{1}{c}{ Aspek } & $\%$ \\
\hline 1 & Menyukai pelajaran matematika & $85 \%$ \\
\hline 2 & Menyukai pelajaran IPA & $85 \%$ \\
\hline 3 & Paham penjumlahan dengan alat timbangan & $75 \%$ \\
\hline 4 & Paham pengurangan dengan alat timbangan & $70 \%$ \\
\hline 5 & Paham perkalian dengan alat timbangan & $60 \%$ \\
\hline 6 & Paham kesetimbangan dengan alat timbangan & $75 \%$ \\
\hline 7 & $\begin{array}{l}\text { Semangat dalam pembelajaran jika menggunakan alat } \\
\text { timbangan }\end{array}$ & $95 \%$ \\
\hline 8 & Kebingungan dalam penggunaan alat timbangan & $0,2 \%$ \\
\hline 9 & Penjelasan alat timbangan kurang jelas & $0,2 \%$ \\
\hline 10 & Lebih paham menghitung biasa daripada dengan alat timbangan & $90 \%$ \\
\hline
\end{tabular}

Berdasarkan paparan Tabel 2 di atas, diperoleh hasil bahwa sebagian besar siswa kelas IIIB sudah memahami penggunaan alat peraga timbangan pada operasi penjumlahan, pengurangan dan perkalian bilangan asli serta materi kesetimbangan di pelajaran IPA sesudah siswa kelas IIIB menerima pelatihan alat peraga timbangan. Berikut disajikan diagram persentase hasil angket kelas IIIA pada Gambar 1. 


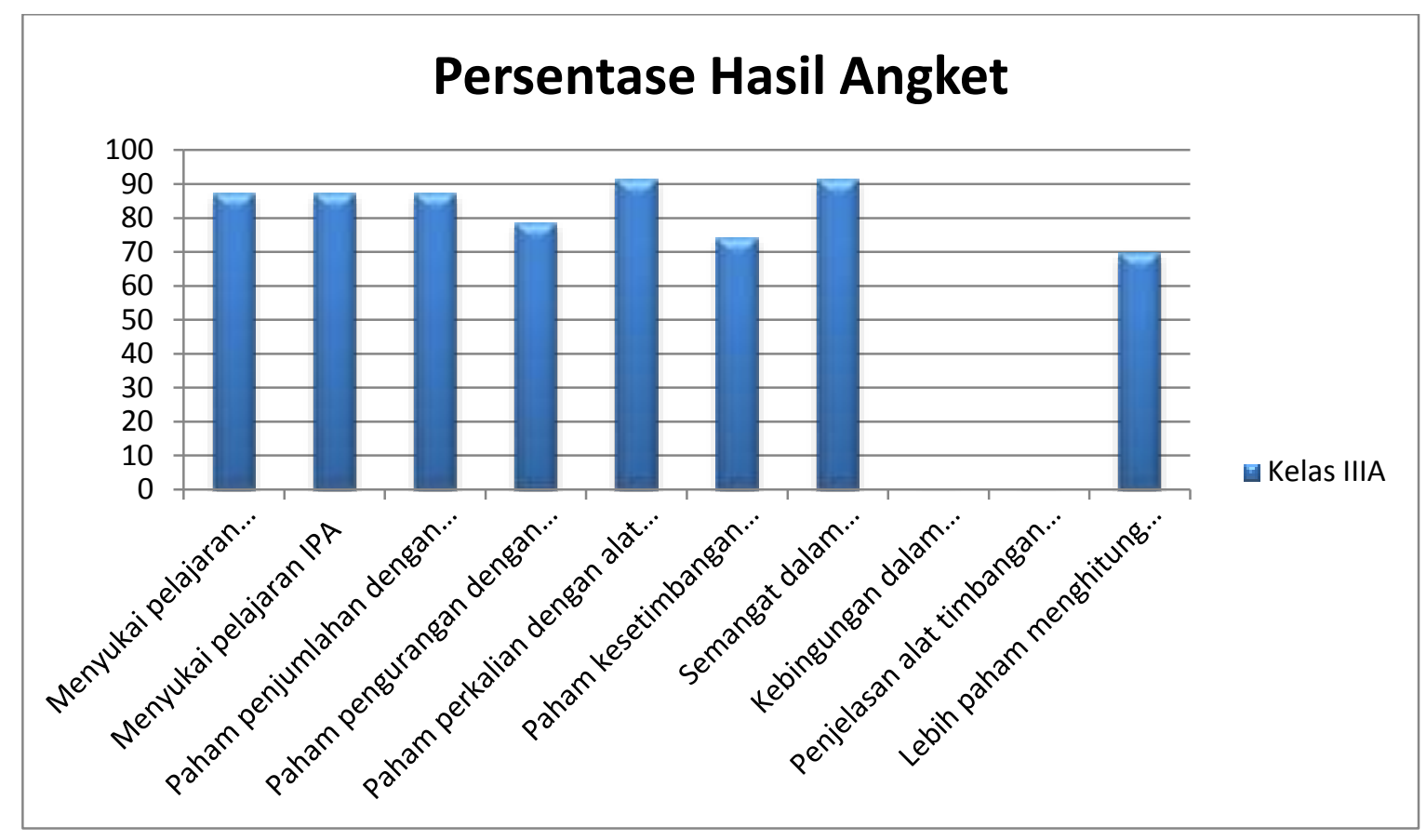

Gambar 1. Diagram Persentase Hasil Angket Kelas IIIA

Di bawah ini juga disajikan dalam bentuk diagram tentang hasil angket kelas IIIB terlihat pada Gambar 2.

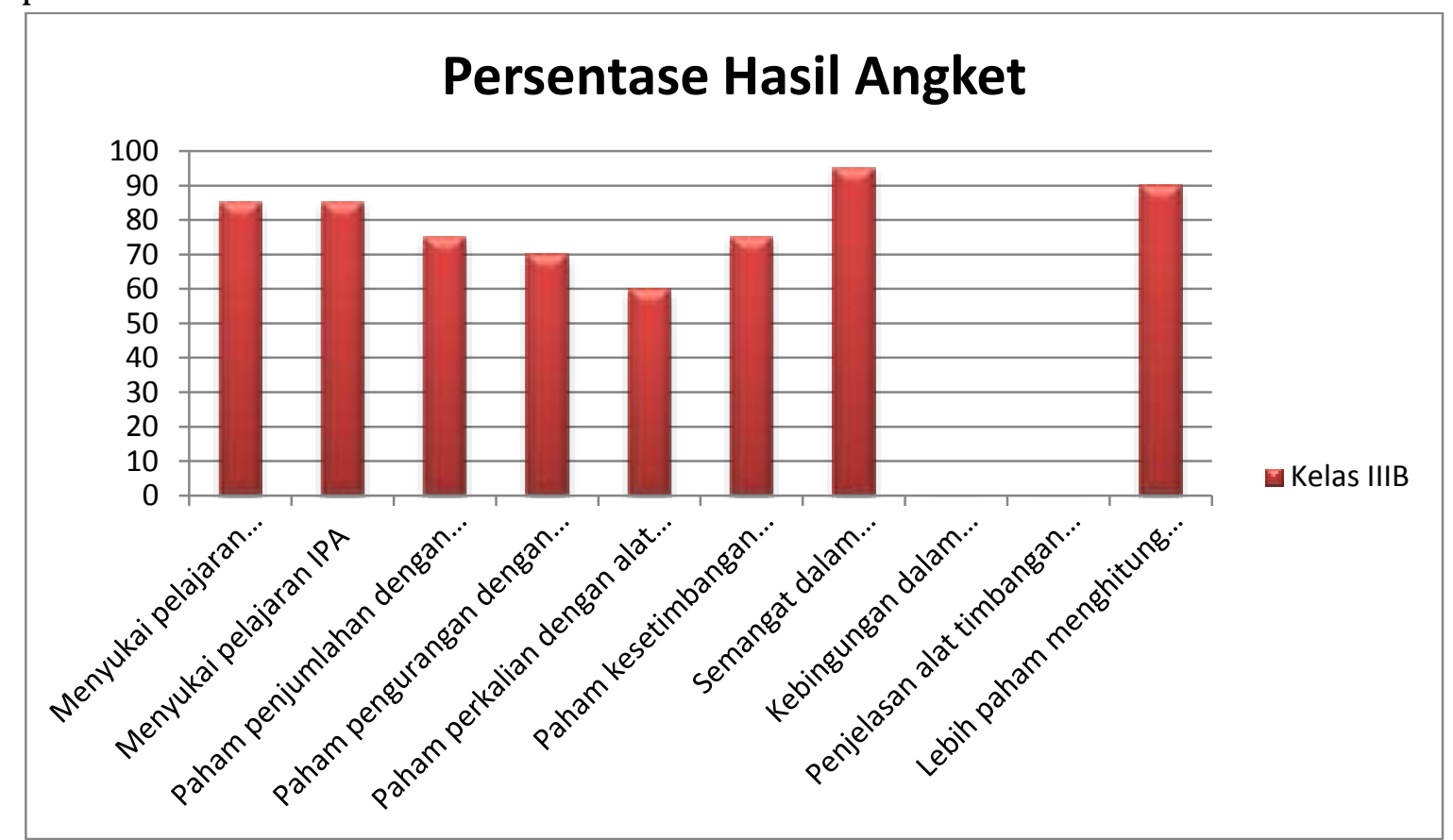

Gambar 2. Diagram Persentase Hasil Angket Kelas IIIB

Berikut juga disajikan perbandingan hasil angket kelas IIIA dan IIIB sesudah diadakannya pelatihan alat peraga timbangan. Diagram hasil angket IIIA dan IIIB disajikan pada Gambar 3. 


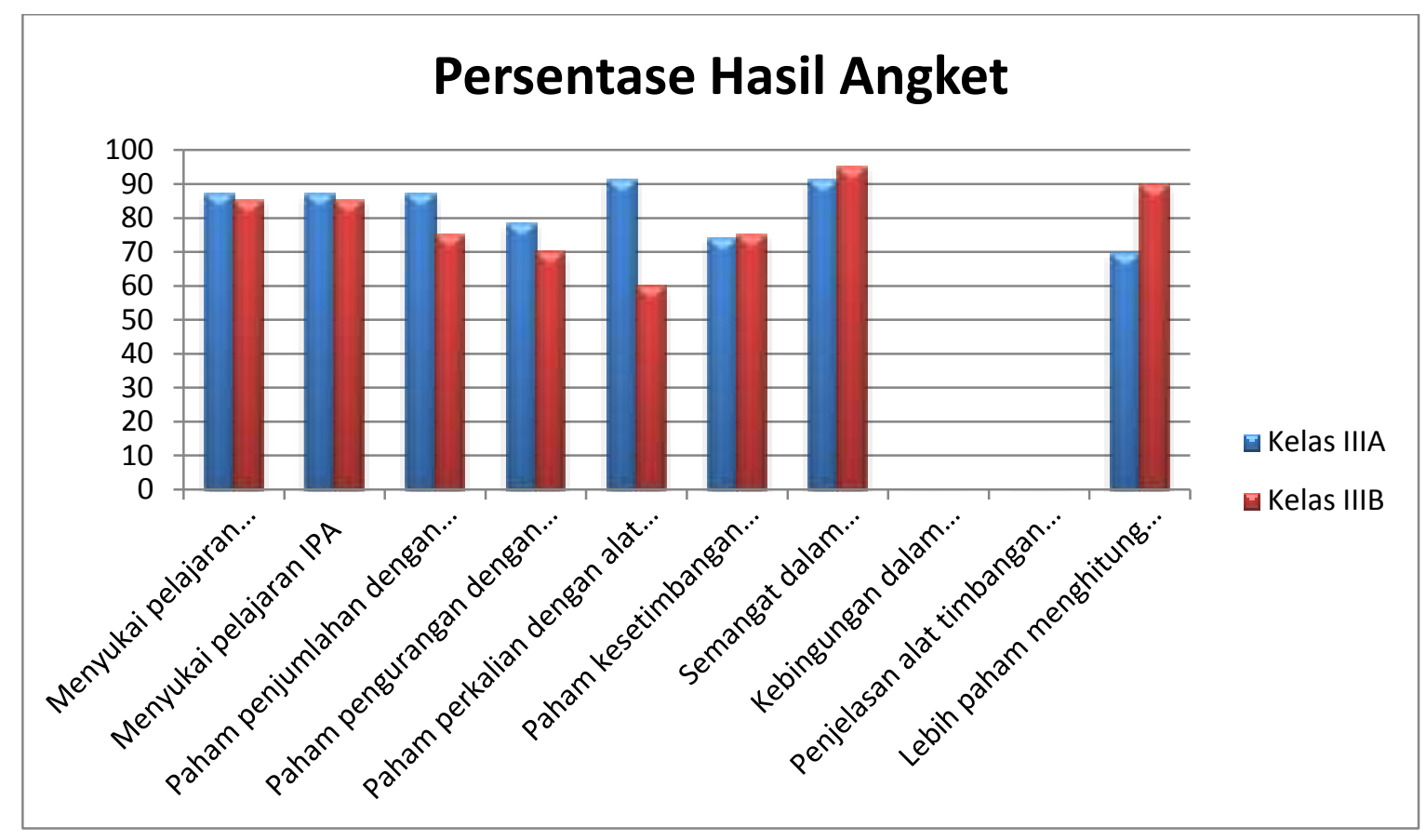

Gambar 3. Diagram Persentase Hasil Angket Kelas IIIA dan IIIB

Pada Gambar 3 terlihat hasil angket kelas IIIA sekaligus IIIB. Persentase tentang pemahaman operasi hitung penjumlahan, pengurangan dan perkalian bilangan asli lebih tinggi kelas IIIA daripada kelas IIIB. Sedangkan pemahaman materi kesetimbangan lebih tinggi kelas IIIB daripada IIIA. Dari Gambar 1 terlihat juga bahwa persentase untuk pernyataan angket tentang kebingungan dalam penggunaan alat peraga timbangan samasama rendah pada kelas IIIA dan IIIB sehingga sebagian besar siswa kelas IIIA dan IIIB memahami penggunaan alat peraga timbangan.

\section{SIMPULAN}

Pelaksanaan pengabdian kepada masyarakat bertempat di MI At Taqwa Rancaekek dengan sasaran siswa kelas IIIA dan IIIB dengan memberikan pelatihan alat peraga timbangan. Dari pelatihan, ternyata siswa mencoba-coba menggantungkan balok untuk jawaban dari soal yang tim pengabdi berikan sehingga timbangan tersebut seimbang. Kesalahan atau kekeliruan yang banyak terjadi pada saat siswa mencoba alat peraga timbangan yaitu kesalahan siswa dalam menggantungkan posisi balok baik di lengan kanan atau lengan kiri. Sedangkan dari hasil angket yang telah diberikan kepada siswa, disimpulkan bahwa sebagian besar siswa sudah memahami operasi bilangan asli yaitu penjumlahan, pengurangan, perkalian, dan kesetimbangan dengan menggunakan alat peraga timbangan. 


\section{DAFTAR RUJUKAN}

Rachmawati, T. K., Suhendar, Y., \& Akbar, R. (2018). Penggunaan Kartu Positif Negatif dalam Menyelesaikan Operasi Hitung Bilangan Bulat. Jurnal Al-Khidmat, Vol.1, No.1, 59-66.

Sari, R. N. (2018, Juli 10). Pengaruh Penggunaan Alat Peraga Timbangan Bilangan Terhadap Pemahaman Konsep Perkalian Di Kelas II SDI Al Azhar 15 Pamulang. FITK UIN Syarif Hidayatullah Jakarta .

Sari, W. M. (2013). Penggunaan Media Timbangan Bilangan untuk Meningkatkan Kemampuan Menjumlahkan Bagi Anak Tunagrahita Ringan. Jurnal Ilmiah Pendidikan Khusus, Vol.1, No.1, 416-427.

Sedyoningrum, Y., \& Supeni, S. (2017). Penggunaan Media Pembelajaran Timbangan Bilangan untuk Meningkatkan Hasil Belajar Matematika Materi Pembagian. Jurnal Mahasiswa UNISRI Progdi PGSD , Vol 2, No 2, 1-13. 